\title{
Depositional characteristics and petroleum geological significance of wetland
}

\author{
Jin Zhenkui ${ }^{1 *}$, Gu Junfeng1, Su Nina ${ }^{1}$, Wang Zhaofeng ${ }^{2}$ and Huang Xiaoping² \\ ${ }^{1}$ State Key Laboratory of Hydrocarbon Resources and Exploration, China University of Petroleum, Beijing 102249, China \\ ${ }^{2}$ Research Institute of Petroleum Exploration and Development, Xinjiang Oilfield Company, PetroChina, Karamay, \\ Xinjiang 834000, China
}

\begin{abstract}
Wetland is a new type of sedimentary facies proposed for the first time in this paper. It is a type of sedimentary environment, transitional between land facies and water (sea or lake) facies. In this paper, wetland is redefined as "a type of sedimentary environments whose ground surface is flat and wet throughout the year, which may be covered with very shallow water (less than $2 \mathrm{~m}$ deep), and is covered with lush plant growth". Wetland is reclassified into two types, swamp wetland (swamp in brief) and wet plain wetland (wet plain in brief). Swamp deposits are coal, while wet plain deposits are dark colored mudstones or silty mudstones rich in plant fossils and carbon debris. The deposits of wet plain are different from those of lake and floodplain in the abundance of plant fossils, color, resistivity well logging curve, and other sedimentary characteristics. In boreholes, resistivity logging can be used to distinguish between wet plain mudstones and lake mudstones. Understanding the sedimentary characteristics of wet plain wetland can help to identify wet plain deposits which were formerly classified as floodplain or lake deposits. This will help to reconstruct the palaeogeography and to understand the history of basin and climate evolution accurately, and is especially important in evaluation of the hydrocarbon generating potential of a basin. With the Jurassic Sangonghe Formation of the Yanqi Basin as an example, the identification characteristics of wetland are described.
\end{abstract}

Key words: Wetland, wet plain, Yanqi Basin, Sangonghe Formation of Jurassic, braided river delta

\section{Introduction}

Although wetland is well studied from the viewpoint of ecology and environment protection (Brockmeyer et al, 1996; Hostedde et al, 2007; Lian, 2006; Lü and Huang, 1998; Meng, 1999; Peng et al, 2008; Yu, 2000; Zhang et al, 2008), it has never been mentioned as a type of sedimentary facies in papers or books on sedimentology and lithofacies paleogeography (Tian, 1997; Wang, 1995; Zeng and Xia, 1986; Zhao and Zhu, 2001). In fact, wetland is developed in many areas on the earth and is a very important type of sedimentary environment, transitional between land facies and water (sea or lake) facies.

In 1971, the "Ramsar Convention on Wetlands" was passed officially in Ramsar in Iran, which provided a framework for wetland protection and international cooperation for each contracting state. In November 1980, the first contracting states congress was held in Cagliari in Italy, and the basic definition of wetland was given. According to the definition, wetland refers to "swamp, wet plain, peat land, or other water covered areas, which may be permanent or temporary, natural or artificial, and may be covered with stagnant or flowing, fresh or salty water including sea with

*Corresponding author. email: jinzhenkui@188.com Received February 16, 2009 depth less than $6 \mathrm{~m}$ at ebb tide" (Wilen and Tiner, 1993). According to this definition, lakes, rivers, ponds, estuaries, mangroves, and marine coastal zones less than $6 \mathrm{~m}$ deep at ebb tide are all grouped into wetland. Obviously, this definition of wetland is too broad, and is not suitable for sedimentary facies study.

In this paper, "wetland" is redefined from the viewpoint of sedimentology for the first time, as "a type of sedimentary environments whose ground surface is flat and wet throughout the year, which may be covered with very shallow water (less than $2 \mathrm{~m}$ deep), and is covered with lush plant growth" (Fig. 1). "Being covered with lush plant growth" is the most important characteristic of wetland defined in this paper. "Flat and wet ground surface which may be covered with very shallow water" is the cause of lush plant growth. Wetland defined in this paper may be called "wetland in a narrow sense", and is different from the former one, which may be called "wetland in a broad sense".

Wetland in a narrow sense can be further classified into two types: swamp wetland (or swamp in brief) and wet plain wetland (or wet plain in brief). Swamp deposits are coal, while wet plain deposits are dark colored mudstones or silty mudstones rich in plant fossils and carbon debris. The deposits of these two types of wetland are completely different. 


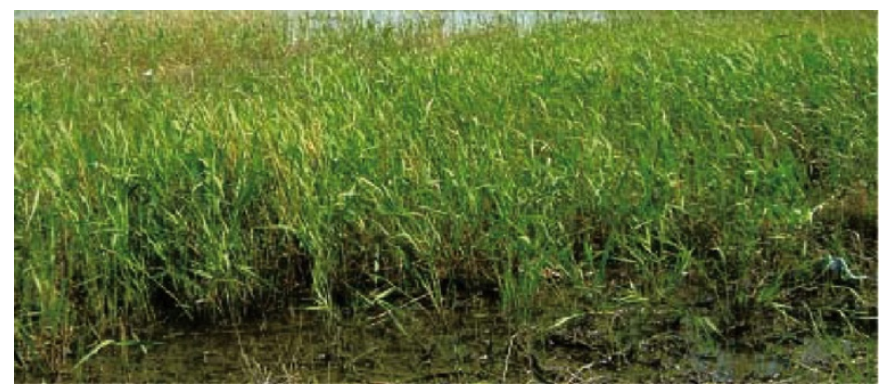

Fig. 1 Modern wet plain wetland

According to the characteristics of modern narrow sense wetlands, wetlands may be developed from filling up of seashores, bays and lakes, from delta plains, and from flat and low land (such as fluvial flood plain, and plain between and before alluvial fans). For example, the wetland developed on the Huanghai coast of northern Jiangsu province is the largest marine wetland in China. It is 582 kilometers long and 243,000 hectares in area. It is formed from mud filling of seashores. The wetlands around the Poyang Lake and Dongting Lake are developed from filling up of the lakes. The wetlands at the Yellow River mouth are formed on the Yellow River delta plain. The wetlands in the Momoge Nature Reserve in Jilin province are developed from flooding and deposition of the Nenjiang River and its tributaries. The wetlands in the Kekexili area result from mountain meltwater. In China, wetlands are mainly distributed in northeast China, east China, northwest China, and the Qinghai-Tibet plateau. The size of the wetlands ranges from hundreds meters or several kilometers to tens of kilometers or hundreds of kilometers in length and width.

Wetlands are mainly developed in wet climate, but can also form in arid climate, such as the reed wetlands developed around the Bositeng Lake in Yanqi County, Xinjiang, and those developed in front of alluvial fans. However, generally speaking, wetlands developed in arid climate are relatively small in area. Wetlands of different origin and developed in different climate have different plant community.

It is easy to identify ancient swamp, because its deposits are coal. The deposits of wet plain are dark mudstones and silty mudstones, which are easily confused with lake and floodplain deposits. In this paper, the identification characteristics of ancient wet plain, its difference from other similar environments, and the significance of accurate identification of ancient wet plain deposits are summarized. Finally, taking the Sangonghe Formation of the lower Jurassic in the Yanqi Basin, Xinjiang as an example, methods for identifying wet plain deposits and their application in analysis of sedimentary facies are discussed.

\section{Sedimentary characteristics of wet plain wetland}

According to the study of the Jurassic deposits in the Junggar Basin and Yanqi Basin in Xinjiang, combined with the investigation of the modern wet plain wetland of Poyang Lake in east China and Bositeng Lake in northwest China, the characteristics of wet plain wetland deposits are summarized as follows:

1) The deposits are fine, mainly mudstones and silty mudstones. Because of the flat topography and the lush plants acting as baffles, the velocity of floods flowing through wetlands is low. So wetland is a low energy environment. The sediments are mainly mud and fine silt transported in suspension during flooding.

2) The deposits are dark, mainly dark grey, greyish black, and black. In the wet plain environment, the ground water table is near or higher than the ground surface, so the soil is full of water, and both ground water and surface water is stagnant. Thus wet plain is a reducing environment, organic matter can be preserved in mudstone, and hence the color of the mudstone is generally dark. The higher the level of organic matter, the darker the color (Fig. 2).

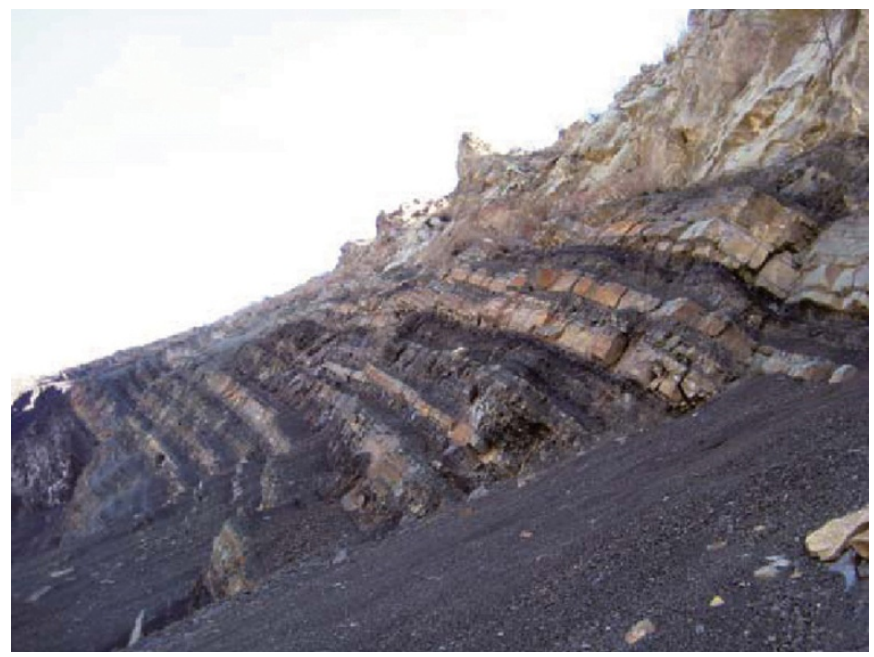

Fig. 2 Wet plain dark mudstone rich in plant fossil, Jurassic, Baiyanghe succession in southern margin of Junggar Basin

3) In wet plain deposits, plant fossils are abundant, and organic matter content is high. Because of the dense plant coverage and the reducing environment, plant fossil remains are abundant in wet plain deposits, and plant roots, stems, leaves, and carbon debris are common. Thus, the content of organic matter in wet plain deposits is high, commonly over $5 \%$, and may reach about $20 \%$, even forming carbonaceous mudstone. However, the organic matter is humic, and can not form good petroleum source rocks.

4) Wet plain deposits are massive in structure, and do not show stratification, but root fossils are common. As plants are dense in a wet plain environment, the root systems are well developed, which can disturb the deposits and destroy stratification. Thus stratification is not developed, and root fossils are common.

5) Because of the abundant plant fossils and the high content of organic carbon, wet plain deposits can be easily identified on resistivity logging curves. The resistivity curve is sawtooth shaped and shows higher resistivity than pure mudstone, but lower than coal and sandstone.

In conclusion, the identification characteristics of ancient wet plain deposits are as follows: the lithology is mudstone, silty mudstone, and carbonaceous mudstone, rich in plant fossils and high in organic carbon content; the color of the 
deposits is mainly dark grey to black; the resistivity logging curve of the deposits is serrate in shape, and the resistivity value is between that of pure mudstone and sandstone.

We think that the reason why wet plain can not form coal but swamp can is that although plants are commonly developed in wet plain wetland environment, the deposition rate of terrigenous mud and silt is still higher than that of plants, and the content of mud and silt in wet plain deposits is over $50 \%$. While in swamp wetland, plants are dense, the deposits mainly consist of organic matter (Jin et al, 2007; 2008), and there is little terrigenous matter being deposited. For wetlands large in area, swamp wetland may develop in the central part of the wetland, while wet plain wetland develops in the marginal areas. In the Jurassic outcrop at the southern margin of the Junggar Basin, dark mudstone deposited in wet plain wetland is interbedded with coal deposited in swamp wetland. This shows that wet plain wetland and swamp wetland are closely associated (both geographically and in time). Of course, these two types of sedimentary environments may occur independently in some cases.

\section{Differences between wet plain deposits and floodplain deposits}

Wet plain deposits are different from floodplain deposits. In previous literature, floodplain is defined as flat land environment located between river channels, inundated only during flooding. It is a sedimentary microfacies belonging to flood basin subfacies in fluvial facies.

The floodplain defined in previous literature in fact includes two types of environments. The first type is a relatively dry oxidizing environment in which plants are rare, its deposits are mudstone and silty mudstone in which plant fossils are rare, and the color of the deposits, usually red, purplish red, or yellowish brown, reflects their oxidation (Jin et al, 2002; 2006). The second type is wet reducing environment in which plants are dense, its deposits are mudstone and silty mudstone in which plant fossils are abundant, and the color of the deposits, usually gray, dark gray, and black, reflects the reducing environment.

Obviously, these two types of environments are very different. They should be distinguished from each other and could not be both called floodplain. We suggest that the first type of environment should be called floodplain, representing dry oxidizing environment with scarce plants and a relatively deep ground water table. It is mainly developed in arid to semiarid climates. The second type of environment should be called wet plain wetland, representing a wet reducing environment with dense plants and a very shallow ground water table. It is mainly developed in wet climates.

Therefore, the major differences between wet plain wetland deposits and floodplain deposits are whether the deposits contain abundant plant fossils and whether the color of the deposits is a reducing color or an oxidizing color.

Wet plain wetland may develop both on floodplain of fluvial depositional systems and on delta plains. Wet plain wetland developed on floodplain could be called "flood wet plain wetland", and wet plain wetland developed on delta plain could be called "interdistributary wet plain wetland". The sedimentary characteristics of flood wet plain wetland are similar to those of interdistributary wet plain wetland, and just the depositional systems in which they occur are different.

\section{Differences between wet plain deposits and lacustrine deposits}

A lake is an underwater environment, and thus mudstone deposited in lake usually shows reducing color, similar to that of wet plain deposits. Although showing reducing color, mudstone deposited in a lake is usually pure and does not contain plant fossils and carbon debris. However, mudstone deposited in wet plain wetland contains abundant plant fossils and carbon debris. This is the most important difference between wet plain and lake deposits.

In addition, in mudstone deposited in lakes, the organic matter type is sapropelic and the organic carbon content is usually less than 5\%. However, in mudstone deposited in wet plain wetland, the organic matter type is humic and the organic carbon content is usually over $5 \%$, reaching $10 \%$ $15 \%$ or even higher.

Therefore, the major differences between wet plain deposits and lacustrine deposits are whether plant fossils and carbon debris are abundant and what type the organic matter is.

\section{Significance of correct identification of wet plain deposits}

It has substantial theoretical and practical significance to identify wet plain deposits correctly and differentiate wet plain wetland from swamp wetland, floodplain, and lake.

Firstly, with knowledge of sedimentary characteristics of wet plains, we can identify the wet plain deposits which were previously believed to be floodplain or lake deposits, then the palaeogeography can be identified correctly, and basin evolution and climate evolution can be understood more accurately. This is important.

Secondly, present determination of lithology and sedimentary facies of underground strata in oilfield mainly relies on borehole rock cutting logging and electrical logging. All dark colored mudstones, as the color is reducing color, are believed to be lake deposits. Almost nobody expects to find plant fossils in the rock cuttings because they are too small in size. If these dark colored mudstones are not lake deposits, but from a wet plain wetland environment, serious mistakes will be made in exploration: 1) A lake may be believed to develop extensively in the basin, and as a lake is a good petroleumgenerating environment, the exploration potential of the basin may be believed to be great. This false evaluation might result in great waste in manpower and material resources. 2) Sandstone intercalated in the dark mudstones, which in fact are fluvial deposits, will be believed to be deltaic or even gravity flow deposits, resulting in incorrect interpretation of the palaeogeography and basin evolution history. This may also have an adverse influence on the petroleum exploration in this basin. 
On outcrop, plant fossils can be easily seen if present, and thus it is easy to distinguish between mudstones deposited in wet plain wetland and those deposited in lake. But how can the distinction be made in boreholes? The following methods can be used:

1) Resistivity logging can be used to distinguish them. Mudstone deposited in wet plain contains abundant plant fossils and is high in organic matter content, so the resistivity of wet plain mudstone is usually higher than that of pure mudstone deposited in lake. Based on the study of Jurassic cores and electrical logging of several tens of wells in Junggar Basin and Yanqi Basin in Xinjiang, the resistivity curves of wet plain mudstone are usually serrated in shape and the resistivity ranges between $6 \Omega \mathrm{m}$ and $10 \Omega \mathrm{m}$, while that of pure mudstone deposited in lake is usually $1-4 \Omega \mathrm{m}$.

2) The abundance of carbon debris in borehole rock cuttings can be used to distinguish them. In mudstone deposited in wet plain, there is abundant carbon debris in addition to plant fossils. In rock cuttings, it is difficult to find large plant fossils, but easy to find carbon debris if present. Therefore, if carbon debris is common in rock cuttings, then the mudstone is wet plain deposits. If there is no carbon debris, then the mudstone is lake deposits.

With the above two methods, it is easy to determine whether the dark mudstone in boreholes is deposited in wet plain or lake.

\section{Case study}

Taking the Jurassic Sangonghe Formation in the Yanqi Basin, Xinjiang as an example, the depositional characteristics of wet plain and lake facies are discussed.

\subsection{Geological setting}

The Yanqi Basin is located in the Bayinguoleng
Mongolian Autonomous Prefecture in Xinjiang, and at the eastern end of the southern Tianshan fold belt. It is a Mesozoic and Cenozoic petroleum-bearing and coal-bearing basin developed from Hercynian fold basement. Its area is $13,000 \mathrm{~km}^{2}$. The basin consists of two depressions and one central uplift (Yuan, 2003), which are the Bohu Depression, Yanqi Uplift, and Hejing Depression from south to north. In the basin, the Triassic, Jurassic, Paleogene, and Neogene are developed. The Jurassic is the major exploration target.

The study area is located in the northern part of the Baolangsumu anticline in the Bohu Depression (Long et al, 2007) (Fig. 3), and its area is about $6 \mathrm{~km}^{2}$. At present, there are 25 wells including five cored wells and three-dimensional seismic data. The lower Jurassic Sangonghe Formation is the producing horizon (Table 1), and is also the horizon studied in this paper.

The Sangonghe Formation of the study area is mainly composed of gray sandstone, fine conglomerate, dark mudstone, and coal. The formation is deposited in braided river deltas under a humid climate, and the evidence includes: 1) The lithology is coarse on the whole. Fine conglomerate is common, and the total content of sandstone and conglomerate is high, reaching $50 \%-60 \%$, which is a typical characteristic of a braided river delta (Wu et al, 1999); 2) Parallel bedding and trough cross bedding are common in sandstone and conglomerate. This reflects high current velocities, also a typical characteristic of a braided river delta; 3 ) The roundness of grains is poor, mostly subangular, which reflects short transportation distance and near-provenance deposition; 4) Sandstone and conglomerate are frequently interbedded with lacustrine mudstone and coal and mudstone deposited on land, showing upward-coarsening sedimentary succession, which is another characteristic of delta deposition.

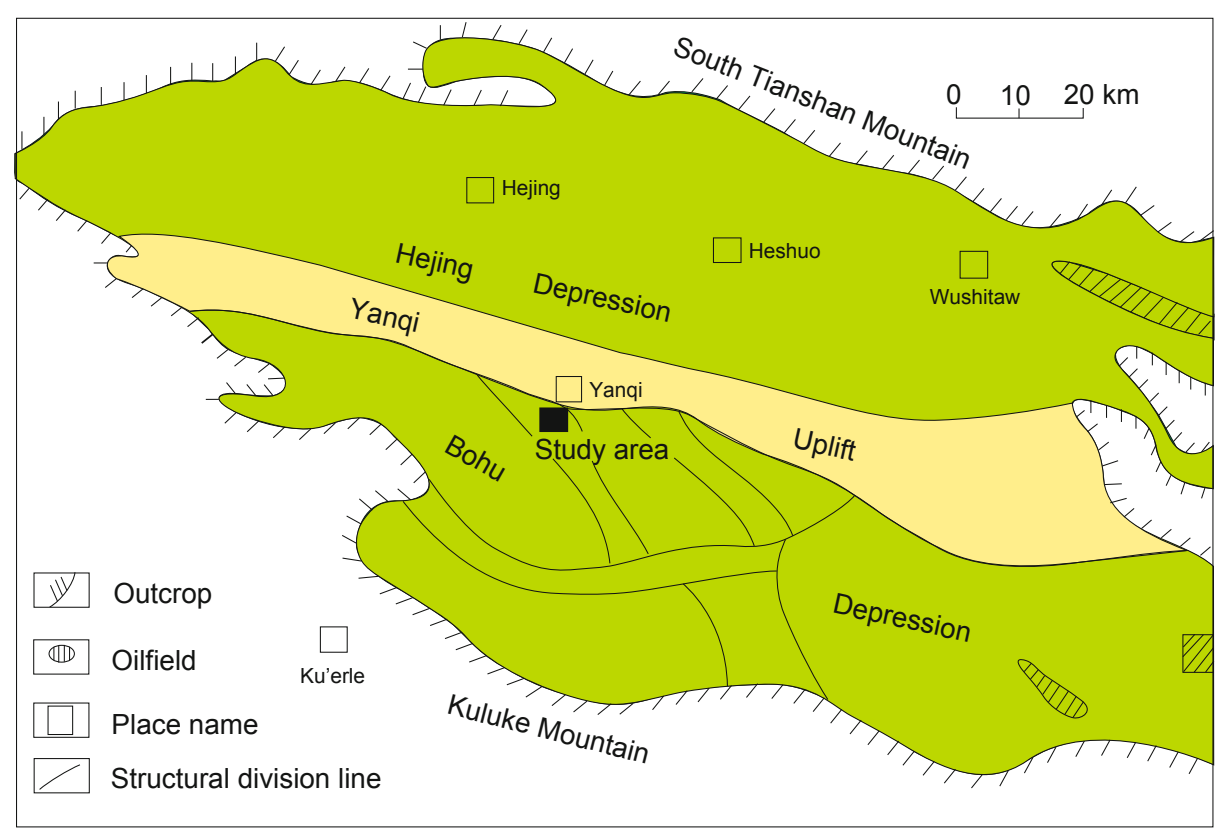

Fig. 3 Structural units of the Yanqi Basin and the location of the study area 
Table 1 Stratigraphy and petrology of the Jurassic of the study area

\begin{tabular}{|c|c|c|c|c|c|c|}
\hline \multicolumn{4}{|c|}{ Stratigraphic unit } & \multirow{2}{*}{$\begin{array}{l}\text { Thickness, } \\
\text { m }\end{array}$} & \multirow{2}{*}{$\begin{array}{l}\text { Tectonic movement and } \\
\text { movement property }\end{array}$} & \multirow{2}{*}{ Rock characteristics } \\
\hline Erathem & System & Series & Formation & & & \\
\hline
\end{tabular}

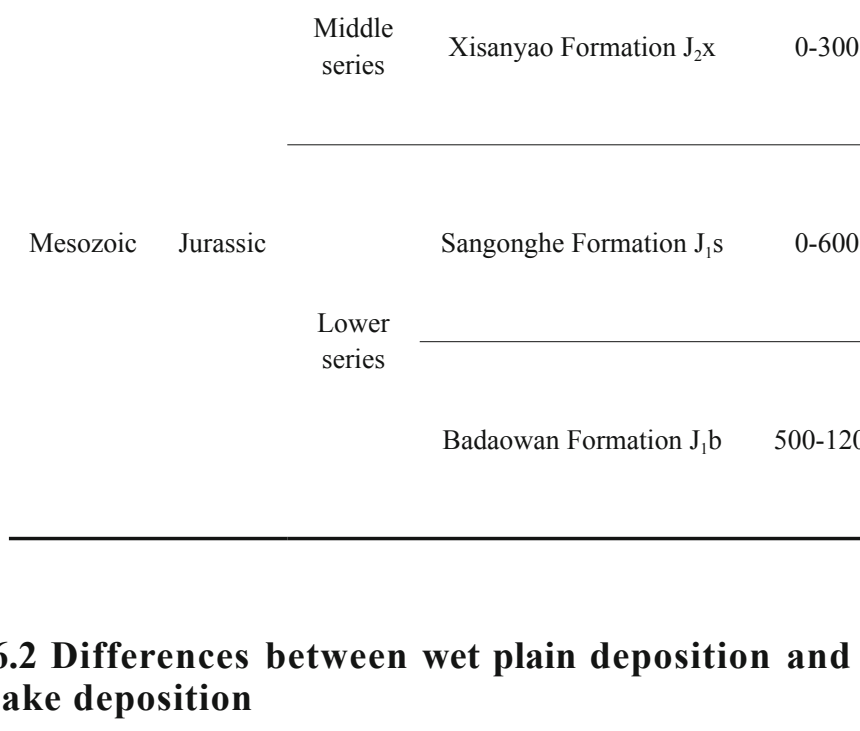

In the Sangonghe Formation of the study area, the color of the mudstone interbedded with sandstone and conglomerate is mainly dark gray and grayish black. Which dark colored mudstones was deposited in a lake and which on a wet plain? How can delta front and delta plain deposits be distinguished?

In cores from wells Bao101, Bao103, and Bao108, it is easy to distinguish between the mudstone deposited on a wet plain and that deposited in lake facies. The former generally contains stem and leaf fossils of plant and carbon debris, and does not show bedding (Figs. 4 and 5). Carbonized plant root fossils are common. Mudstone deposited in a lake is pure, and does not contain plant fossils and carbon debris, and horizontal bedding is well developed (Fig. 6). Ostracod fossils are common.

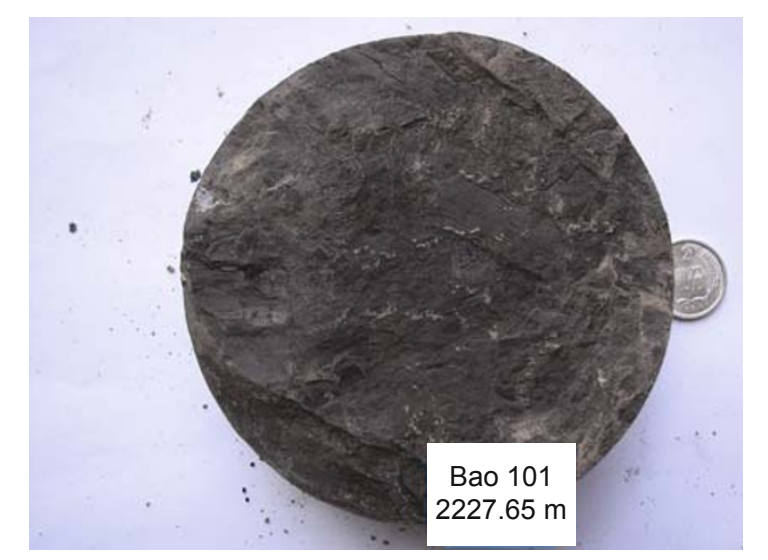

Fig. 4 Mudstone deposited in a wet plain, rich in plant
fossils and carbon debris, Well Bao101 (2,227.65 m),
Jurassic Sangonghe Formation in Yanqi Basin, Xinjiang

Fig. 4 Mudstone deposited in a wet plain, rich in plant
fossils and carbon debris, Well Bao101 (2,227.65 m),
Jurassic Sangonghe Formation in Yanqi Basin, Xinjiang

Fig. 4 Mudstone deposited in a wet plain, rich in plant
fossils and carbon debris, Well Bao101 (2,227.65 m),
Jurassic Sangonghe Formation in Yanqi Basin, Xinjiang

\subsection{Differences between wet plain deposition and} fossils are common. grey mudstone, silty mudstone, coal seam interbedded with light grey sandy conglomerate and fine sandstone

grey fine sandstone, fine conglomerate, and sandy conglomerate intercalated with charcoal grey mudstone and coal seam

grey pebble sandstone interbedded with charcoal grey mudstone and grey black carbonaceous mudstone intercalated with coal seam, siltstone, and fine conglomerate

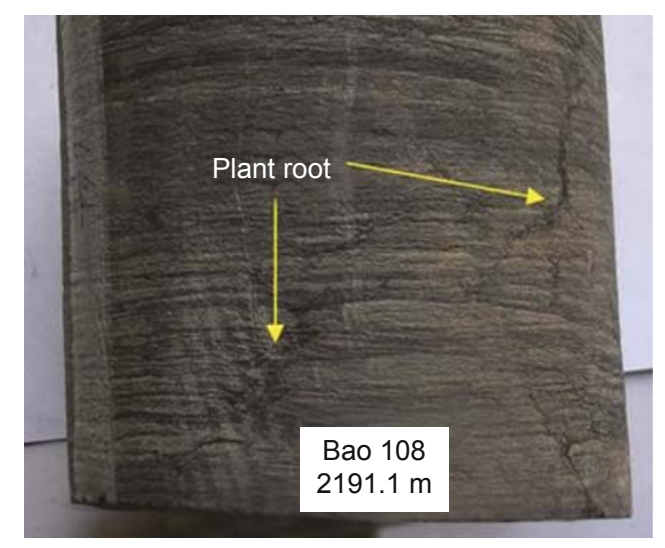

Fig. 5 Silty mudstone deposited in a wet plain. Plant root fossils are common. Well Bao108 (2,191.1 m), Jurassic Sangonghe Formation in Yanqi Basin, Xinjiang

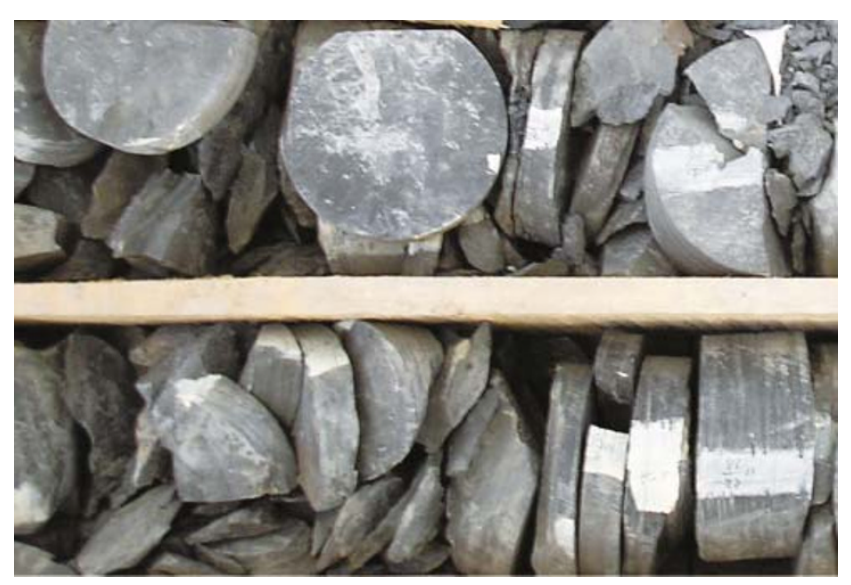

Fig. 6 Pure lake mudstone containing no plant fossil or carbon debris, Jurassic Sangonghe Formation, Well Bao101, Yanqi Basin, Xinjiang 
Based on the logging curve characteristics of different types of rock, it is found that the resistivity curve can be used to distinguish wet plain mudstone and lake mudstone, but other logging curves can not. In the study area, because of the higher organic matter content, the resistivity of wet plain mudstone is usually higher than that of lake mudstone. The organic matter content of coal deposited in swamp is almost $100 \%$, so its resistivity is the highest (Figs. 7 and 8 ). The resistivity of wet plain mudstone is usually 6
$\Omega \mathrm{m}-10 \Omega \mathrm{m}$, and that of lake mudstone is usually less than $4 \Omega \mathrm{m}$, around $3 \Omega \mathrm{m}$ (Figs. 7 and 8 ). According to the logging characteristics of the two types of mudstone, it is easy to distinguish wet plain mudstone from lake mudstone in intervals that are not cored, so it is also easy to distinguish between delta plain and delta front. This is of great significance to reconstruction of palaeogeographical environments, correct evaluation of the scope of the lake, and the distribution of the source rock.

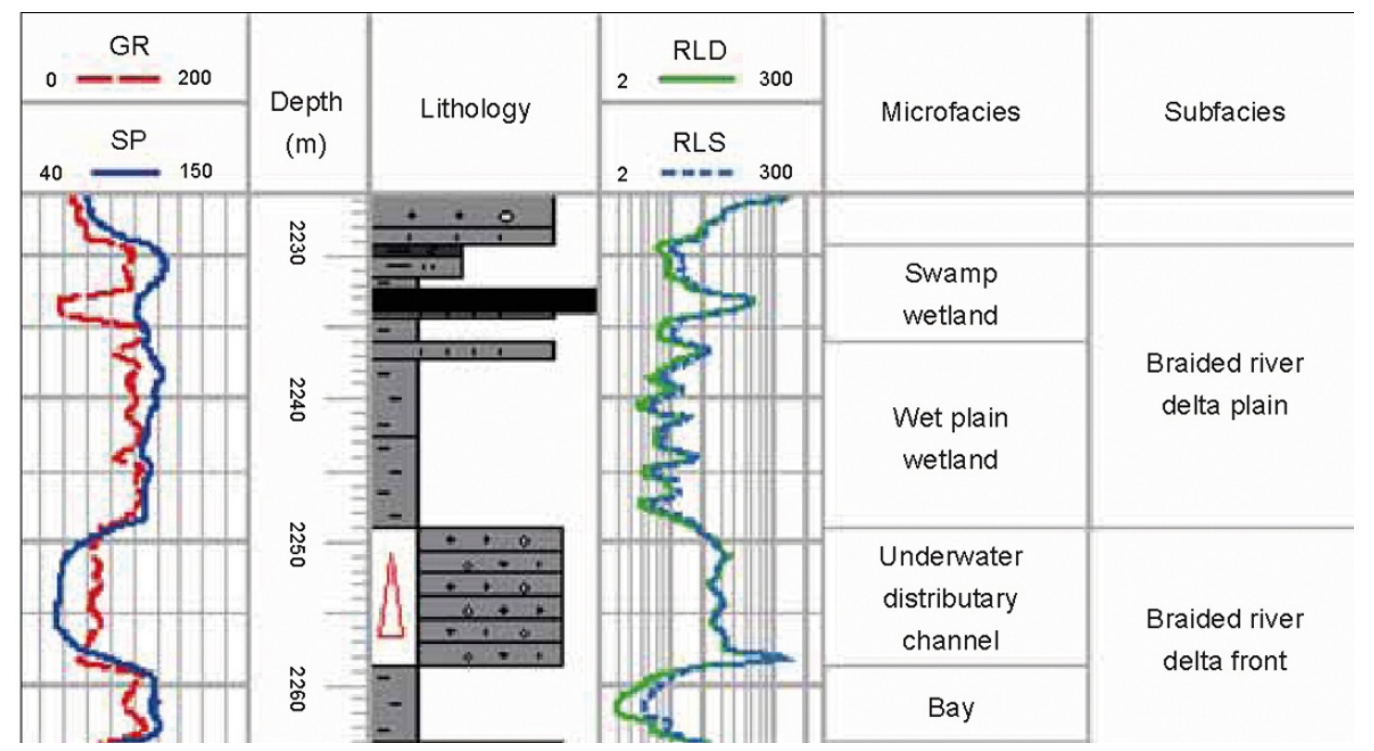

Fig. 7 Electrical logging characteristics of wet plain wetland, swamp wetland, and underwater interdistributary bay (lake) of delta front deposits in Well Bao108, Yanqi Basin, Xinjiang

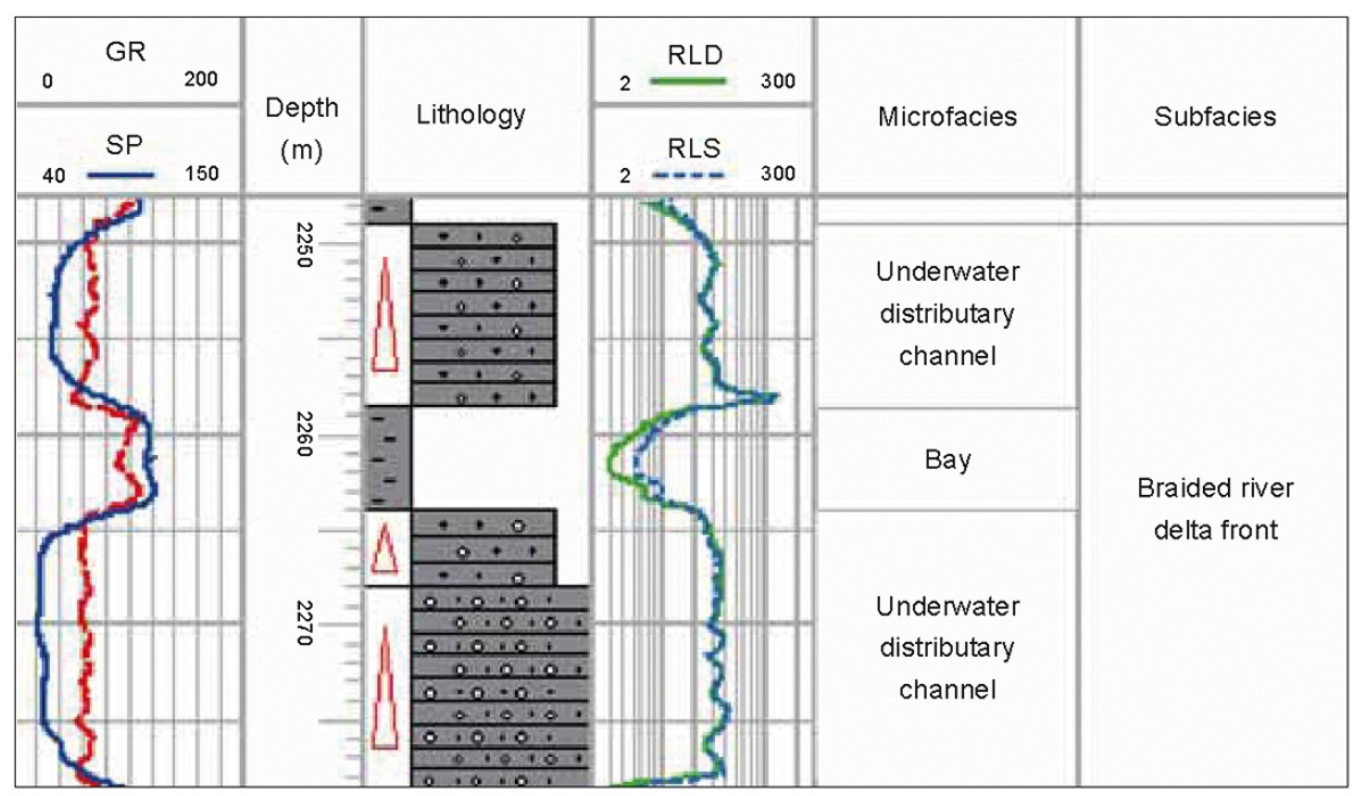

Fig. 8 Electrical logging characteristics of underwater interdistributary bay (lake) of delta front deposits in Well Bao103, Yanqi Basin, Xinjiang

\section{Conclusions}

Wetland can be divided into two types, swamp wetland and wet plain wetland. Swamp deposits are coal, while wet plain deposits are dark colored mudstones or silty mudstones rich in plant fossils and carbon debris. The deposits of wet plain are different from those of lake and floodplain in the abundance of plant fossils, color, resistivity well logging 
curve, and other sedimentary characteristics. Correct identification of wet plain deposits is helpful in reconstructing the palaeogeography and understanding the history of basin and climate evolution accurately. Correct differentiation between wet plain deposits and lake deposits is especially important in evaluation of the hydrocarbon generating potential of a basin.

\section{Acknowledgements}

This study is financially supported by the "973" National Major Fundamental Research \& Development Project "Reservoir-forming mechanism and distribution law of oil and gas in superimposed basins of China" (2006C13202300).

\section{References}

Brockmeyer R E, Rey J R, Virnstein R W, et al. Rehabilitation of impounded estuarine wetlands by hydrologic reconnection to the Indian River Lagoon, Florida (USA). Wetlands Ecology and Management. 1996. 4(2): 93-109

Hostedde B S, Walters D, Powell C, et al. Wetland management: An analysis of past practice and recent policy changes in Ontario. Journal of Environmental Management. 2007. 82(1): 83-94

Jin Z K, Qi C W, Xue J Q, et al. Sedimentary facies of the Jurassic in the northern margin of Qaidam Basin. Journal of Palaeogeography. 2006. 8(2): 199-209 (in Chinese)

Jin Z K, Su N N and Wang C S. Controlling factors of reservoir of coal rocks in Carboniferous-Permian, North China. Acta Geologica Sinica. 2008. 82(10): 1323-1329 (in Chinese)

Jin Z K, Wang C S, Wang P, et al. Controlling factors of reservoir ability of Carboniferous and Permian coal rocks, North China. Petroleum Exploration and Development. 2007. 34(5): 534-540 (in Chinese)

Jin Z K, Zhang X X, Zou Y R, et al. Quantitative study of sedimentary facies of the lower part of Xiaganchaigou Formation of Paleogene of Shaxi Oilfield in Qinghai Province. Journal of Palaeogeography.
2002. 4(4): 99-107 (in Chinese)

Lian J G. Main wetlands in China and protective suggestions. Resources Environment and Development. 2006. (1): 30-32 (in Chinese)

Long G Q, Deng H W, Liu B, et al. Base level cycle and reservoir macroscopic heterogeneity of the Sangonghe Formation in Baolang Oilfield. Petroleum Geology and Engineering. 2007. 21(2): 13-17 (in Chinese)

Lü X G and Huang X C. Progress in wetland research in China. Scientia Geographica Sinica. 1998. 18(4): 294-300 (in Chinese)

Meng X M. Wetlands and Global Environmental Change. Scientia Geographica Sinica. 1999. 19(5): 385-391 (in Chinese)

Peng Y S, Zhou Y W and Chen G Z. The restoration of mangrove wetland: a review. Acta Ecologica Sinica. 2008. 28(2): 786-792 (in Chinese)

Tian Z Y. Lithofacies Palaeogeography and Hydrocarbon of Petroliferous Basin in China. Beijing: Geological Publishing House. 1997 (in Chinese)

Wang Y H. New Progress of Sedimentology and Lithofacies Palaeogeography. Beijing: Petroleum Industry Press. 1995 (in Chinese)

Wilen B O and Tiner R W. Wetlands of the United States. In: Wetlands of the World I. Netherlands: Kluver Academic Publishers. 1993

Wu S H, Jin Z K, Huang C D, et al. Reservoir Modeling. Beijing: Petroleum Industry Press. 1999 (in Chinese)

Yuan Z W. Analysis on structural evolution in Yanqi Basin. Journal of Jianghan Petroleum Institute. 2003. 25(4): 33-35 (in Chinese)

Yu G Y. Respect and prospect of the wetland research in China. World Sci-Tech R \& D. 2000. 22(3): 61-66 (in Chinese)

Zeng Y F and Xia W J. Sedimentary Petrology. Beijing: Geological Publishing House. 1986 (in Chinese)

Zhang Y M, Zhao S D and Guo R C. Global wetlands: Status and trends, scenarios and response options. Advances in Earth Science. 2008. 23(4): 415-420 (in Chinese)

Zhao C L and Zhu X M. Sedimentary Petrology (Third Edition). Beijing: Petroleum Industry Press. 2001. 229-233 (in Chinese)

(Edited by Hao Jie) 